\title{
Frank Farmer
}

\section{Dial ogue and Critique: Bakhtin and the Cultural Studies Writing Classroom}

\author{
I repeated the line, "the idea was so simple, \\ anyone could [have] thought of it, but it was so \\ obvious that it never occurred to me." I said that \\ this was what a cultural critic needed to be able to \\ do: to notice those simple-seeming, obvious things \\ that usually go unnoticed. I said that this was what \\ cultural theory was good for, hel ping us to see \\ what is ordinarily invisible to the people who \\ are actually members of the culture being \\ studied. I said I thought this writer had \\ understood that concept, and had become a \\ cultural critic.
}

-Kathleen Dixon (112)

that expresses the kind of epiphany that would be pleasing to any writing teacher, but perhaps especially gratifying to those writing teachers who employ a cultural studies perspective in their classrooms. This is so be cause insight for the cultural studies teacher is not simply a fortuitous, cursory moment in the process of rhetorical invention but is, indeed, the very heart of cultural critique.

I would like to suggest further, that what Dixon reveals in this passage may well be the central dilemma faced by instructors who teach from a cultural studies perspective - namely, the difficulty in making a liberatory

Frank Farmer is an associate professor of English at East Carolina University where he teaches writing and graduate courses in rhetorical theory and history. His articles have previously appeared in Rhetoric Review, Focuses, Rhetoric Society Quarterly, Composition Studies, and elsewhere. He has recently edited a collection, Landmark Essays on Bakhtin, Rhetoric, and Writing. This article is part of a larger project to explore affinities between dialogue and theory, especially as they intersect in the writing classroom. 
agenda comport with a distinctive, seemingly privileged way of knowing. Thus, in the excerpt above, Dixon establishes that cultural criticism is incontestably democratic by virtue of its free availability to all ("anyone could [have] thought of it") and yet is, at the same time, necessary because its epiphanies are often "invisible to the members of the culture being studied." The need for the cultural critic, then, appears to rest on the presumed blindness (or inattention) of ordinary people, whom, we are led to believe, need considerable help in seeing not merely what the critic sees, but what the critic sees through. Further, there exists an underlying suggestion here that the cultural critic is as likely to be at ease in meritocratic real ms as in democratic ones. The last line of this excerpt, for instance, recognizes an important accomplishment by the student, followed by the conferral of well-earned praise from the teacher, who bestows said praise apparently on the presumption that the student has some manifest desire to "become a cultural critic."

According to Michael Bérubé, cultural studies discovers itself to be a "volatile enterprise" because the so-called "ordinary people" it seeks to enlighten al ready have in place "their own descriptive languages for themselves... which serve the purposes of enunciating group identities, practices and self-definitions" (166). Far too often, the self-definitions held by "ordinary people" are not the ones preferred by cultural critics who aim to discover "new knowledges for and about ordinary people" (176). Cultural studies, a frankly "oppositional" discourse, often finds itself being opposed by the selfsame groups with which it hopes to establish alliances. Notwithstanding its liberatory aspirations, cultural studies is thus seen by many as elitist or authoritarian in its methods and goals.

Of course, that observation has been made before, and in several different contexts. Yet the issue is of particular moment to composition specialists because the site of our most important work - as scholars and teachers - is the classroom. For this reason, I believe, we are especially attuned to the difficulties involved in knowing how to teach in a manner that both respects our students' views and, at the same time, questions the complacencies which too often inform those views. Thus, for writing teachers who adopt a cultural studies perspective, caveats like this one from Donald Lazere speak of the need to establish a degree of balance in the composition classroom:

I am firmly opposed...to instructors imposing socialist (or feminist, or Third World, or gay) ideology on students as the one true faith-just as much as I am opposed to the present, generally unquestioned (and even unconscious) imposition of capitalist, white male, heterosexual ideology that pervades American education and every other aspect of our culture. (195) 
Something of a dual sensibility toward students emerges here: a poising of the actual and the possible, a simultaneous nod to experience and discernment.

Along these same lines, J oseph Harris wonders if doing cultural studies must necessarily mean "speaking in the name of someone who fails to see what we do, or who falls for things we don't" (28). Harris observes that there exists "a deep anti-democratic impulse" among those who would speak for "the other reader." What results from this distrust of the other's experience is the (ironically Platonic) view that any unwitting otherreader, student, consumer-basically "can't be trusted," and should, therefore, be protected "against the influences of popular and thus suspect texts" (30). Much like Lazere, Harris senses the need for some balance in our approach to ideology in the writing classroom. Our classrooms, Harris argues, ought to be places where students "can write as people who are, at once, rock fans and intellectuals... [where] they can write the pleasures as well as the problems they find in popular texts" (35). Affirming our students' capacity to simultaneously experience and critique the culture they live in, Harris maintains, should provide a useful check against the temptation to make our students into those "other readers" whom we "speak for" rather than "listen to and learn from" (36).

But what, precisely, are we apt to find out by listening to our students? One likely discovery, according to Bérubé, is that the public at large (including our students, of course) is already accomplished in cultural criticism, is already familiar with many of the operative assumptions of cultural theory. "Do we," Bérubé asks, "have to introduce publishers, futures traders, and real estate agents [and I would add, students] to the idea that there's no such thing as 'intrinsic' merit, that merit is a social phenomenon?" Or likewise, regarding those who watch The Larry Sanders Show, Bérubé asks, "do we really need to acquaint them with the idea of the simulacrum?" (166). The alleged elitism of cultural studies, then, may repose in our seeming indifference to what ordinary people al ready know. As J an Zta Grover puts it, "that so much academic cultural criticism... proceeds in willed ignorance of non-academics' ability to use and critique the materials of what academics like to believe is their own-and exclusive-toolbox has nurtured an understandable resentment among its putative subjects" (229).

And yet, behind this affirmation of student awareness lurks a rather disconcerting possibility: If our students are al ready accomplished in cultural criticism, what is it that we presume to teach? Or, more worrisome for writing teachers perhaps, if our students are already able to generate the kinds of insights noted by Dixon and Bérubé, and can do so without our help, do we not risk slipping into a kind of de facto current-traditionalism wherein our pedagogies are once again confined to "what's left over," that is, to matters of correctness and style? Two answers are typically offered on 
behalf of teachers at this juncture. One argues that while it is true our students know a great deal about the meanings of popular culture in their lives, they have yet to realize that they possess this knowledge. And since they don't know they know, a good measure of teacherly intervention is necessary. Apart from the obviously patronizing attitude embedded in this view ("I know what you know better than you do"), such an answer does little to remove us from the original charge of elitism and, in fact, lends considerable force to arguments that would seek to maintain a hierarchicallyordered classroom.

The second response, a more pragmatic one, revises the first to read something like this: our students know a great deal about the meanings of popular culture in their lives, but they have yet to realize how this knowledge might alter the world they live in. In this praxis-inspired approach, the teacher's responsibility is to help students know how and where they might transform their own history. But as Lawrence Grossberg has observed, such a position assumes "that the teacher understands the right techniques to enable emancipatory and transformative action" (92). I would add that this position also bestows upon the teacher a knowledge regarding which actions are appropriate to which situations, when those actions are to be performed, how and by whom, and perhaps even such tactical minutiae as when to delay action for long range purposes. In any event, the teacher once again possesses a special knowledge which, as Grossberg points out, "understands history, and people's positions within it, better than they do" (92).

Is there any way, then, to imagine a teacher's role that doesn't require a caste knowledge that teachers and critics possess, but that many students feel intentionally excluded from? I believe this is an urgent question for composition teachers, and one that, as I will argue below, may find an answer in how successful we are in bringing together the distinct, but mutually tempering, virtues of dialogue and critique. Before elaborating this argument, I wish to begin with an example from one of my classes.

\section{An Illustration}

Two years ago, I taught a section of Advanced Composition to a class of English and English Education majors. Since this was an "advanced" course, most of my students were juniors and seniors. In addition, most were women, most were white, and most, as they cheerfully informed me, were taking this course because it was required by their particular specialty. As I have done in the past, I selected the most recent edition of Bartholomae and Petrosky's Ways of Reading to be the required text for this course. ${ }^{1}$ The unit I report on here, "Popular Culture," included two selections by 
Mark Crispin Miller, "Getting Dirty" and "Cosby Knows Best," and one by J ohn Fiske, "Madonna." This unit created a forum for the student voices to be heard momentarily.

At the beginning of the unit, I hoped my students would engage the brand of popular criticism offered by Miller and Fiske. I assumed that by reading these two critics, by reflecting upon and discussing the kinds of operations that Miller and Fiske were deft at performing - in other words, that by having the right opportunity-my students could "do" cultural critique. The exploratory writing assignment for this last unit, then, was for students to choose a local, cultural phenomenon for comment and analysis. The papers I got in response to this prompt were, however, disappointing. Though I received a predictable smattering of good essays, on the whole the papers had that telltale "flatness" about them, that lackluster quality that makes writing teachers question the assignment that encouraged such responses. What baffled me most was the extent to which my students' papers were at odds with the typically raucous, sometimes heated, al ways unpredictable class discussions on the assigned readings. For the most part, very little of the energy that animated those class discussions could be heard in my students' essays.

In thinking about this situation, I began to suspect that what truly interested my students had little to do with The Cosby Show but a great deal to do with Miller, little to do with Madonna but a great deal to do with Fiske. What genuinely seemed to interest my students was the problem of trying to figure out exactly what Miller and Fiske were up to: Why, my students wondered, are these "reviews" so unlike the reviews we read in newspapers? Who gave critics the "right" to pass judgments on those who watch TV or follow Madonna? Why did they waste their interpretive talents on the banalities of media icons? Why did they see the "ordinary viewer" with such obvious contempt? Who could they possibly be writing this stuff for?

Wanting to tap the vitality of our discussions, I devised a final assignment slightly modified from one suggested in our textbook (175):

Mark Crispin Miller and J ohn Fiske both write extensively about the larger, cultural meanings of what's usually referred to as "popular culture." While they write about different cultural forms or objects, they both try to imagine the mind and response of the consuming public. That is, both Miller and Fiske have a need to theorize the viewer, reader, or listener.

In an essay of three to four (typed, processed) pages, describe and examine the figure of the consumer (the "common" viewer or reader?) and the figure of the critic (the "uncommon" reader or viewer?) as represented by these two writers. Conclude your essay with your thoughts on the relationship of critics and criticism to the world of the ordinary consumer. ${ }^{2}$ 
What follows are excerpts from student responses to this assignment, along with my commentary. ${ }^{3}$ I begin with a sampling of passages that document my students' resistance to the critiques of Miller and Fiske:

Though Miller and Fiske represent the consumer as the couch potato, I get the feeling that the critics are a bunch of people (and for some reason I always picture men -1 guess the women are out buying Shield and pseudofeminism) smoking pipes and laughing appreciatively at the picture of the consumer...I get the feeling that these articles were talked over in the country club and then put into print so that the critics' friends could see. The critics are obviously not part of the consumer group-they see the 'truth' behind the commercials, TV shows, and musicians and don't buy into it.... Basically, the consumers are the comedy show for the critics. Whatever will those couch potatoes buy next? (Barbara)

Both see the consumer as mindless and naive. Each seems to see himself, the insightful critic, as just the person to show the blind and stupid consumer the way to the light of social awareness... The critic is there to enlighten.... while the consumer is there to learn how society works through the careful guidance of the critic. (Elaine)

Even in our class there was dissension about the Cosby essay because a lot of people in our age group grew up watching Cosby, as well as listening to Madonna and watching commercials. No one likes to be made to look like a fool, especially for doing something that almost everyone does, almost every day.... Maybe the "common world" rejects their essays because members of that world are a part of the subject being looked at. (Sam)

But another problem these critics have... is their lack of ability to communicate with the "common reader." They write on levels that can only satisfy one another and never break the barrier between themselves, the "uncommon reader," and the "common reader." Because of this fact, they will always get people asking questions like, "What the hell are they writing about anyway?" (Shannon)

Either the consumer really is blind to reality and the critic realizes this, or the consumer is not and the critic must construct situations where the consumer is made to believe he is blind. At any rate, the critic must always be, or at least seem, one step higher in perception and knowledge than the consumer. In many ways the cultural critic is no different from the artistic or literary critic: he depends on the ignorance of his audience. ${ }^{4}$ (Alex)

Viewers enjoy the [Cosby] show even more because it gives us a way to pretend that everything is all right in the world. We are attracted to shows like the Cosby Show because they give us a form of escape. With the Huxstables we can pretend, if only for thirty minutes, that the United States does not 
have an economic problem among minority groups. We can pretend that our children, of all ethnic groups, are in the same class bracket and are "getting along." (Carol)

Fiske differs from Miller in the sense that Fiske tends to give the consumer a little more credit. His analysis of Madonna as an icon of popular culture tries to explore the minds of her fans.... Fiske sees the young girls that emulate Madonna as newly-liberated females. His perspective that young girls use Madonna's cultural imagery to rebel against patriarchy may indicate his willingness to personify those fans as a reflection of his own intellect. At the same time, he tends to acknowledge that the fans may not be cognizant of their rebellious impulses. The need for translation equates with a need for someone like Fiske. (Scott)

On the surface of things, responses such as these-for the cultural studies writing teacher anyway-could be read as distressing. Indeed, my students' comments seem to lend force to the usual reports of the conservative, if not reactionary, views that our students hold. Yet, while my students clearly resented what they perceived to be "elitist" representations of themselves at the hands of Miller and Fiske, their responses were, in fact, far more complex than this sprinkling of excerpts suggest. If my students lend credence to anything, I would argue, it is to the idea forwarded by Bérubé, Grover, and others that they already possess a "toolbox" able to equip them with all the necessary implements required to perform cultural critique. More pointedly, I would argue, my students' comments speak to a need to consider how dialogue might complement the project of ideological critique which cultural studies embraces, and, indeed, depends upon.

In the pages to follow, I want to demonstrate a Bakhtinian approach to the problem outlined above. I offer this approach knowing that when dialogue is linked to cultural studies, it typically emerges through the pedagogical theories of Paulo Freire, a thinker quite distinct from Bakhtin but one who shares a number of theoretical affinities with Bakhtin's understanding of dialogue. Such affinities, for example, can be seen in Diana George's and Diana Shoos's attempt to illustrate Freire's eschewal of "sectarian" impositions (left or right) to address the problem I have tried to formulate here:

If we judge our students' work by whether or not they come to the same conclusions we do, we not only send them conflicting messages about their own worth as thinkers but al so insure our own failure as teachers. The function of teachers within the paradigm of a liberatory pedagogy is to allow and 
encourage our students to become radical thinkers in the sense of coming to their own conclusions, given a raised consciousness. (201-02)

George and Shoos argue that the best way to accomplish such a goal is to establish dialogic classrooms "of exchange and reciprocity" (206). They recommend, among other things, choosing texts about which the teacher has not formed any final judgments so that students and teachers can engage the kind of dialogic inquiry that Freire sees as transformative.

But while choosing texts unfamiliar to both teacher and student, no doubt, helps to establish the conditions for mutual inquiry, an exclusive focus on content does not guarantee a dialogic pedagogy. It may well be that at some moment in the process of exploring a "new" text, for example, the teacher's insights become the tacit standard, the official line to which students feel considerable pressure to conform. As teachers, moreover, do we really wish to exclude from our classrooms all those texts which we al ready have some familiarity with, which we've thought over, struggled with, maybe even changed our minds about? Clearly, then, we need to turn our attention to the manner in which we present texts, to the ways we might conceive pedagogies that foster the kind of dialogic exchange that Freire, and others, wish to effect. Mikhail Bakhtin, I believe, can help us in this project-though perhaps not in the manner we have typically come to expect.

\section{Problems of Bakhtinian Critique}

It is by now something of a commonplace that Bakhtin's value to critique may be limited, if not altogether suspect. Certainly, there are any number of appropriations that enlist Bakhtin in service to critical projects, but these appropriations tend to put aside that substantial body of work that falls under the rubric of what Michael Bernard-Donals calls the "phenomenological" Bakhtin, a thinker whose concerns are largely ethical and aesthetic, and whose thought is decidedly shaped by the neo-Kantian milieu that he sought to address. On the other hand, those who find in Bakhtin a thinker who might contribute to any project of cultural critique typically draw on the "social" (or what Bernard-Donals and others call the "Marxist") Bakhtin, relying extensively on certain works of the 1930s and 1940s, or sometimes assigning dual or pseudonymous authorship to Bakhtin of earlier works signed by his colleagues, V. N. Voloshinov and Pavel Medvedev. Though the authorship question is too thorny and persistent to adequately broach here, what certain scholars find in these works (especially those signed by Voloshinov) is a powerful social semiotics from an avowedly Marxist perspective. And yet, the wellspring for much, if not 
most, Bakhtinian-inspired critique is to be found not so much in the disputed texts, but rather in those works of the 1930s and 1940s. And the single most important concept to be appropriated from these writings is the idea of carnival, a theme found in a number of essays but most thoroughly elaborated by Bakhtin in Rabelais and $\mathrm{H}$ is World.

Carnival, though, has proven to be a highly vexed and problematic notion. To be sure, carnival is the chosen turnstile through which many Bakhtinian ideas gain entrance into the arena of cultural studies. And for good reason. Not only does carnival place an enormous faith in popular forms of resistance, in the ability of the "lowly" to travesty the high monologism of all things official, authoritative, and sacrosanct, it does so without patronizing or dismissing the folk and their potential for insurgent laughter. In this respect, Bakhtin seems to have avoided the cultural elitism of, say, Frankfurt school Marxism which, as Michael Gardiner has pointed out, "vastly underestimated the heterogeneity and variety of contemporary culture, and how these cultural forms absorbed and reflected many different elements and influences in ways that simply could not be reduced to standardization and political or ideological domination" (189). Gardiner mentions Theodor Adorno's famously contemptuous remarks on jazz as perhaps the most obvious example of how Eurocentric ideological criticism has a long tradition of looking at popular culture as "irrevocably degraded or commodified" (189).

That said, Bakhtinian carnival has been vulnerable to the charge that it represents a lamentable naiveté regarding the workings - subtle, disguised, or overt-of the forces of power and domination. More damning, perhaps, is the view that carnival is not so much a reversal of existing social hierarchies as it is a sanctioning of their legitimacy-a criticism that looks upon organized, "permitted" laughter as complicitous in the power arrangements it parodies or travesties. Subversive laughter, in other words, may not be all that subversive when at carnival's end, the temporarily-suspended hierarchies of a dominant order return with a ferocity that is happily assented to by all. In such an event, it would appear that carnival's primary function is to insure that the authentically transformative moment is missed or forgotten, that emancipatory possibility is siphoned off by a thoroughly orchestrated laughter which, when all is said and done, amounts to little more than a celebration of what it purports to mock. Such, at least, is a rough sketch of what I understand to be the putative failings of Bakhtin's carnival (see, for example, Bernstein; Gardiner 17882; Eagleton, Benjamin 148).

While I do not underestimate the difficulties in making Bakhtin's ideas "square" with present forms of cultural critique, and while I too, would agree that carnival is a notion that has serious limitations in this regard, I 
think that if we look more closely at his entire corpus, we might find other possibilities, other entry points for a Bakhtinian understanding of how cultural critique might appear in our classrooms.

\section{Anacrisis and the Superaddressee}

I want to offer two Bakhtinian concepts, anacrisis and the superaddressee, for the purpose of bringing dialogue and critique more closely together. Bakhtin's discussion of the former is most fully addressed in an early work, Problems of Dostoevsky's Poetics; and his discussion of the latter is best explained in one of his last essays, "The Problem of the Text," from Speech Genres and Other Late Essays. Of the many ideas to be found in Bakhtin's rich corpus, these are perhaps two of the more unlikely concepts to fulfill my announced purpose. That is, anacrisis and the superaddressee would typically be thought to represent Bakhtin at his most traditional and humanistic - anacrisis because it seems to affirm a Platonic understanding of dialogue, and the superaddressee because such an idea seems to champion a transcendental worldview. But let us examine each a bit more closely.

\section{Anacrisis}

In his study of Dostoevsky, Bakhtin identifies two "basic devices" of the Socratic dialogue: syncrisis, which Bakhtin defines as "the juxtaposition of various points of view," and anacrisis, which he defines as "the provocation of the word by the word" (110-11). These definitions are offered within the context of Bakhtin's efforts to ascribe to Socrates a dialogic approach to truth and "human thinking about truth" (110). But in order to make this ascription, Bakhtin must separate what he understands to be the novelized genre of the Socratic dialogue from the heavy-handed, catechistic, philosophical monologism of Plato. He does so by arguing that Socrates-the Socrates of the early dialogues, at least-rejects the "ready-made truths" of the later dialogues. That is, according to Bakhtin, this early Socrates had yet to be transformed into a "teacher" (in the strictly pedantic sense of that title), and the Socratic dial ogue had yet to enter service to the "worldviews of various philosophical schools and religious doctrines" (110).

This early Socrates, Bakhtin argues, knew that "truth" was neither born nor found in individual consciousness, but rather was something that could only occur "between people collectively searching for truth, in the process of their dialogic interaction." As an expert questioner, Socrates was, of course, accomplished in the arts of anacrisis: "He knew how to force people to speak...to drag the going truths out into the light of day," and the most important consequence of these promptings was to dialogize 
thought, to "turn [thought] into a rejoinder," and likewise, we may assume, to turn all extant truths into rejoinders as well-answers to the provocative words of others (110-11). ${ }^{5}$

But "going truths" is a telling phrase. Not only does it imply that the one truth usually associated with Platonic epistemology is rather the many truths of dialogue, there is also the clear suggestion that these multiple truths are passing ones, that is, truths that are temporally-situated, contingent. Anacrisis, then, like the project of cultural studies, aims to expose the historicity, the conventionality of the truths we embrace. And yet, the task of revealing situated truths is one made peculiarly difficult by the conditions of our moment. Neither the early Socrates, nor the early Bakhtin, for that matter, could have anticipated how the "going truths" of our time and place are disseminated through the ubiquitous venues of popular culture. Nor could either thinker have foreseen the sophistication with which our going truths are purveyed, especially the manner in which they are simultaneously disguised and invoked. These limitations notwithstanding, the characteristic feature of anacrisis, according to Bakhtin, is that it compels the participatory word, and to the extent that contemporary forms of popular culture may be interrogated by the participatory word, the writing classroom seems to be one obvious site for anacritic explorations. The project of uncovering the hidden truths of the day, therefore, is a dialogic one, a task characterized by mutual inquiry ensuing from the provocative words we speak and engage, the utterances we author and answer.

But isn't this too simple an explanation? Doesn't such an appropriation leave a great deal more to account for? As I noted above, Bakhtin's arguments seem to be conveniently indifferent to the power relations that inevitably attend the problem of who may speak to whom and under what conditions. This charge is familiar enough among those who hear in the valorized term, dialogue, a liberal-humanist palliative. But Aaron Fogel has shown us that it is not only the grand term dialogue that is susceptible to this charge; anacrisis, as well, is a word that bears scrutiny.

Fogel notes that Bakhtin's usage of anacrisis is one at profound odds with the word's etymology. In its ancient Greek sense, anacrisis referred to a form of interrogation often accompanied by torture. Later, in Roman law, and in allusions to Roman law in Pauline scripture, anacrisis becomes more commonly associated with a sort of preliminary hearing leading to a formal trial. As Fogel is quick to observe, Bakhtin's usage renders the term even more benign, removing from it any hint of physical violence or legal compulsion, so that the term can be properly fitted to Bakhtin's conception of a dial ogic truth. Fogel suggests that Bakhtin must possess a remarkable innocence not to be aware that all speech is constrained-and that some speech is violently constrained. Fogel rejects a conception of 
“'dialogue' as simple interpersonal freedom, as something inherently 'mutual,' 'sympathetic,' or 'good'" (193).

But Fogel makes a number of rhetorical moves that are in direct opposition to Bakhtin's understanding of dialogue. Fogel's suggestion that Bakhtin's usage of anacrisis veers from the original meaning of that word, seems to carry with it a certain prohibition against the kinds of revoicing that Bakhtin saw as inevitable and productive. Moreover, this impulse toward an originary can also be seen when Fogel imagines an Oedipal scene for dialogue, a locus for social contracts that govern how dialogues within the group-be these "Quaker meeting, the talk show, 'playing the dozens,'" (193) and so on-are to proceed. One effect of these implicit claims about the possibility of first words (a possibility that Bakhtin denies, of course) is to enable Fogel to emphasize the initiatory, if not originary, quality of coerced speech. Fogel points out that "if there is to be 'dial ogue,' someone must make it happen"(193), an assumption that leads him to posit an "Oedipus dialogue complex" that fulfills precisely this function (196).

But what if the words of the provocateur are provoked themselves? Missing from Fogel's understanding of anacrisis, in other words, is its responsive character. Fogel seems to imagine what Bakhtin does not: a first speaker who is not only capable of disturbing the "eternal silence of the universe," but whose coercive speech is able to return the universe to a desired quiescence. So figured, anacritic speech-whether in the voiced words of the inquisitor, the lawyer, or the teacher-is something wholly autonomous, uncomplicated and unconditioned by prior utterances and anticipated rejoinders. It does not recognize the speech of the oppressor to be thoroughly imbricated in, and thus always, to some extent, determined by the speech of the oppressed. And since hegemonic language can be revealed by the hidden polemics that it conducts with those voices that interrogate or oppose it (Bialostosky 221), one task of what might be called an anacritic approach to cultural studies, then, would be to expose such hidden polemics wherever they may be found.

Of course, the kind of utterance most likely to reveal the hidden polemics that hegemonic discourse conducts is the direct question. Yet, Bakhtin warns that questioning of a certain sort-what he refers to as pedagogical questioning - can too easily settle into ritual forms of catechism that are hostile to the unpredictability of authentic dialogue. When that happens, what emerges are ready-made answers to ready-madequestions, and what might have once been "a genuine question," one that allows for the possibility of surprise, has now become, in Nancy Welch's phrase, "a prescription masquerading beneath a question mark" (499). When we ask students to parrot the viewpoints of a Miller or a Fiske, or to rehearse the truths we 
embrace, we serve notice that we aren't especially interested in what they have to say. On the other hand, the corrective to this heavy-handed approach does not mean that we merely recognize and accept whatever "they have to say" in a misguided attempt at benevolent neutrality. Dialogue is likewise abandoned when we fail to answer the received, catechistic, wellrehearsed truths that students bring to our classrooms. Allowing their "going truths" to stand unanswered is as contrary to genuine dialogue as requiring that they adopt our own.

And what, then, of our "going truths" in the classroom? Or to put this differently, what do we do with the social and political commitments we bring to our writing classes?

True, if our utterances are only questions, we might be able to disguise our stances in a pose of disinterested inquiry. But, as Bakhtin reminds us, utterances encompass a broad range of speech genres, and it seems unlikely that we could limit ourselves only to the questions we put to our students. It also seems unlikely that amidst the happenstance discourse of the classroom-the desultory asides, comments, silences, assertions, quips, sighs, whispers, and so on-we could ever hide from students our positions on the matters we choose to investigate with them under the pretense of an enlightened neutrality. Yet, Bakhtin would ask, why should we?

In what way would it enrich the event if I merged with the other, and instead of two there would now only be one? And what would I myself gain by the other's merging with me? If he did, he would surely see and know no more than what I see and know myself.... Let him rather remain on the outside of me, for in that position he can see and know what I myself do not see and do not know from my own place, and he can essentially enrich the event of my own life.... When there are two of us, then, what is important is... not the fact that, besides myself, there is one more person of essentially the same kind (two persons) but the fact that the other is for me a different person. ("Author and Hero" 87-88)

In the context of this discussion, Bakhtin shows us why the desire to withhold our own commitments from students, even when motivated by an admirable sense of fairness, is ultimately a mistaken one. For to the extent that we silence our positions, we withhold from students some measure of the salutary otherness that could potentially enrich whatever understanding they have of their positions. And yet, at the same time, should we insist that our students merely reprise our truths, perhaps in the catechistic manner described above, then we deny to them the very otherness that could enrich our understanding. Take away our mutual outsider status in relation to one another, and we remove from our classrooms the condi- 
tions for dialogue, and thus for Bakhtin, the possibility of meaning anything to one another at all.

As teachers, especially teachers of cultural approaches to writing, we might do well to add to our repertoire of pedagogical roles the figure of provocateur, one who drags the "going truths out into the light of day," one accomplished in the dialogic arts of anacrisis. This means, among other things, that we encourage the responsive word but not the silencing one, the probing word but not the last one. Any dialogic understanding, Bakhtin tells us in the Dostoevsky book, can only happen between people, "collectively searching for truth, in the process of their dialogic interaction" (110). Short of this, we risk becoming the kind of teacher who would flourish in what Bakhtin refers to as "an environment of philosophical monologism." That is, we become "someone who knows and possesses the truth," and who gladly "instructs someone who is ignorant of it and in error" (81). In such an environment, no one could possibly change anyone else's mind-surely an unwanted (if not ironic) consequence for those, like J ames Berlin and Terry Eagleton, who have suggested clear affinities between ancient rhetoric and contemporary forms of ideological critique. ${ }^{6}$

\section{The Superaddressee}

In Speech Genres and Other Late Essays, Bakhtin provides the fullest account of his theory of the utterance. After exploring the qualities which determine his "metalinguistics," Bakhtin introduces us to a sort of hovering figure that he identifies as a "constituent aspect" of every utterance, an invisibly present "third party" beyond the second party who is embodied in the person of our immediate addressee. Bakhtin refers to this third party as the "superaddressee" and understands such a third party to be an inevitability of speaking:

But in addition to this addressee (the second party), the author of the utterance, with a greater or lesser awareness, always presupposes a higher superaddressee (third), whose absolutely just responsive understanding is presumed, either in some metaphysical distance or in distant historical time (the loophole addressee). In various ages and with various understandings of the world, the superaddressee and his ideally true responsive understanding assume various ideological expressions (God, absolute truth, the court of dispassionate human consciousness, the people, the court of history, science, and so forth). (Speech 126)

One of the key functions of a superaddressee is to provide speakers with a "loophole" through which they can flee the oppressions of immediacy. 
In fact, Bakhtin seems rather baffled by that speaker who "fears the third party and seeks only temporary recognition... from immediate addressees" (127). This is so because he believes that a speaker "can never turn over his whole self and his speech work to the complete and final will of addressees who are on hand or nearby" (126). Bakhtin realizes that authoring an utterance, however innocuous such an activity might seem, is always a hazardous undertaking. From the speaker's point of view, the act of uttering is ineluctably fraught with the potential-some might say likelihood-of infinite misunderstandings. Because this is so, we hedge our (speakerly) bets by invoking a third party who will listen to us, who will understand perfectly what we have to say. We do so realizing that we cannot depend upon our immediates for the understanding we desire.

And yet, far more disastrous than not being understood is the possibility of not being heard at all. Something inescapably violent accompanies those contexts where no hearing is possible. Hence, for Bakhtin, "there is nothing more terrible than a lack of response," and to emphasize this point, he refers to "the Fascist torture chamber or hell in Thomas Mann as absolute lack of being heard, as the absolute absence of a third party" (126-27). The very act of uttering, then, demands that we face not only the possibility of being misheard, but also the possibility of no available hearing whatsoever. And to avoid this terror, we invoke another listener, a potential respondent who is at once "invisibly present" but also (and necessarily) elsewhere. As Michael Holquist observes, "poets who feel misunderstood in their lifetimes, martyrs for lost possible political causes, quite ordinary people lost in quiet lives of desperation-all have been correct to hope that outside the tyranny of the present there is a possible addressee who will understand them" (Dialogism 38).

Given the examples offered by Holquist, we might surmise that what allows "poets," "martyrs," and "quite ordinary people" to act at all is the possibility for an understanding beyond the limited one available to us in existing circumstances. The suggestion here is that our ability to act cannot be separated from our ability to posit, to imagine, to hope for future contexts where our words have a just hearing. Another way to put this is that we cannot avoid constructing normative "utterances" by and through our actions. For Bakhtin, the reverse is true as well: Because utterances are acts, which is to say, because utterances are intoned with value, they invoke a more perfect hearer-or, rather, a more perfect context for hearing - than the one available to us in our immediate circumstances. ${ }^{7}$ In one Bakhtinian sense, then, to say is to say what ought to be.

This is why I think Bakhtin's third party is better thought of as a rhetorical figure than a transcendental one. True, as Holquist points out, "if there is something like a God concept in Bakhtin, it is surely the superaddress- 
ee" (Introduction xviii). And yet, Bakhtin himself cautions against limiting the superaddressee to a strictly theological interpretation. Not only does he provide a list of other likely superaddressees ("the people, the court of history, science," etc.), he specifically warns that this third party "is not any mystical or metaphysical being," even while acknowledging that "given a certain understanding of the world, he [the superaddressee] can be expressed as such" (Speech 126). What seems to intrigue Bakhtin is not so much the possible divinity of a superaddressee but rather what he refers to elsewhere as "the problem of distant contexts," those invoked places and moments where the superaddressee listens from. ${ }^{8}$ Understood this way, Bakhtin seems primarily interested in how "distant contexts" may be discovered within immediate ones-or, more precisely, how normative possibilities are always, already present in the very act of utterance.

This idea bears a remarkable similarity to J ürgen Habermas's theory of communicative competence, especially his Chomsky-inspired notion of an "ideal speech situation" that may be reconstructed from "systematically distorted" instances of actual speech. Habermas believes all discourse to be warped by extra-discursive forces - so much so, in fact, that the mutilating influences of dominant ideology pervade "from the inside out," as it were, all of our utterances, all conversational exchanges of any kind. But while Habermas believes that ideological distortion is systematic, he does not hold that it is all-pervasive. And because he does not regard it to be complete, Habermas is able to claim (à la Chomsky) that our common, everyday words contain within their saying a deep structure of rational communication, a clue as to what a "perfect hearing" or, in Habermas's terms, an "ideal speech situation" might consist of. As Terry Eagleton says of Habermas, so long as dialogue is coercively restrained, our utterances of necessity "refer themselves forward to some altered social conditions where they might be 'redeemed'" (Ideology 130).

Although there are important differences between the two, the Habermasian "ideal speech situation" sounds very much like the Bakhtinian superaddressee, especially when we focus on the contextual rather than the personal implications of the latter. ${ }^{9}$ In fact, viewed from a Habermasian perspective, the superaddressee is required precisely because inequalities habitually obtain between interlocutors, because dialogue is al ways constrained by the power interests that impinge upon it. The superaddressee, in other words, may signify Bakhtin's tacit recognition of the very thing he is often charged with ignoring: namely, the asymmetric relationships of power that shape the manner and direction in which any given dialogue is to proceed. When our utterances are constrained, silenced, misunderstood, interrupted, or otherwise unacknowledged, we quite understandably invoke a better context for their hearing than the one in which we 
speak. And for this reason, the superaddressee may prove to be useful in our approaches to critical pedagogy.

I believe there are (at least) two ways that the superaddressee could be introduced to writing classrooms that incorporate a cultural studies perspective. The first has to do with the classroom analysis of popular forms and representations, our critiques of magazine ads, billboards, sitcoms, movies, lyrics, web pages, and so on. To offer but one method suggested by Bruce McComiskey, we may choose to turn our attentions to how, say, a given advertisement fits within a cycle of production, distribution, and consumption-emphasizing, in particular, the heuristic value of these moments to our analysis of cultural processes. But the superaddressee might serve a similar heuristic function by asking us to examine the manner in which that same ad may offer clues to desirable conditions beyond its own "saying," whether it intends to or not. Recalling Fredric Jameson on this point, Terry Eagl eton explains how a "utopian kernel" might be discerned within even the most commonplace of materials:

Ideologies, cultural formations, and works of art may well operate as strategic "containments" of real contradictions; but they also gesture, if only by virtue of their collective form, to possibilities beyond this oppressive condition. On this argument, even such "degraded" modes of gratification as pulp fiction encode some frail impulse to a more durable fulfillment, and thus dimly prefigure the shape of the good society. (Ideology 184-85)

In other words, with sufficient effort, we may come to discover that our most pervasive and everyday ideological materials point to "some more desirable state of affairs in which men and women would feel less hel pless, fearful, and bereft of meaning" (184). To illustrate how this might be so, Eagleton alludes to Walter Benjamin's study of 19th century Parisian society, a context wherein Benjamin "finds a buried promise of happiness and abundance in the very consumerist fantasies of the Parisian bourgeoisie" (185). Perhaps more relevant to this discussion, Eagleton mentions Ernst Bloch who, in his Principle of Hope, was able to discern "glimmerings of utopia" within "that most apparently unpromising of all materials, advertising slogans" (185).

Taken together, what these thinkers suggest is that our critiques must not be limited to exposing contradictions, unmasking cultural codes, revealing the dominant interests that shape contemporary discourse. Our critiques must also seek to discern the possible in the actual, to discover within the imposed limits of our present situation, those "hoped for" contexts where people might feel "less helpless, fearful, and bereft of meaning." The latter is no less a project of uncovering, and surely no less demanding of our effort and imagination. 
In my own class, for example, The Cosby Show was vehemently defended by my students against what they felt to be unfair criticisms offered by Mark Crispin Miller. A common theme in my students' responses to Miller centered upon why he chose to "tear down" the good life presupposed in images of the Huxstables as a flourishing, happy, well-educated, uppermiddle class black family. Miller's point, of course, is that such images are meant to camouflage the palpable antagonisms that exist between races and classes in late 20th century America. In Miller's view, the "good life" proffered by the Huxstables is little more than a consumerist fantasy land, a showcase for pricey merchandise, exquisitely appointed interiors, and conspicuously fashionable sweaters.

But if we take seriously the idea that even The Cosby Show might be able to suggest altered social conditions - "glimmerings" of hope, so to speakthen both Miller and my students need to be challenged: Miller because he appears to be satisfied not to offer any alternative to the "good life" presented by The Cosby Show; my students because they seemed content not to imagine any alternative to the same "good life." Part of my task, then, was to explore with students what else the Huxstables might tell us about other possibilities besides the obvious ones available to us in the drama itself. I began by asking students to think about what social realities the show might be trying to address. What conditions, in other words, might these images of affluence be compensation for? If we choose to imagine the show as a symbolic "corrective" to certain social ills, exactly what are those ills, and what is the Huxstable vision of the kind of "good life" where those ills no longer exist? Or, to put the same point in Bakhtinian terms, if we think of The Cosby Show as an answer to certain oppressive conditions, is it therefore a satisfactory answer? Is it the only answer? And if together we can imagine an alternative to the good life presupposed by The Cosby Show, what would it be like? How would it differ from everyday life with the Huxstables? Where might it be the same? Questioning of this sort reinforces the notion that any critique of social reality must entail a social imaginary as well.

The second way the superaddressee might be useful in our classrooms is far more reflexive. If, as I have argued, the superaddressee represents Bakhtin's unspoken awareness that differences in power and privilege do, indeed, determine who may speak to whom and under what conditions, then the superaddressee invites us to turn our attention to the classroom as the most obvious context where dialogue is largely shaped by the asymmetric relationships that exist between teachers and students. There may be considerable value in exploring, then, the constraints upon dialogue in our classrooms. Which, for example, result from teacher policies? Which from institutional demands? Which from tacitly agreed upon conventions 
and expectations? Additionally, how do such constraints dictate the manner of speaking in class, and in what ways do such forces shape the writing done for this particular course? Lastly, of course, can we posit a better context for learning - and learning to write-than the one we currently inhabit together? And if so, what can we do to make that imagined context an actual one?

Those readers familiar with liberatory pedagogy will see that we have returned to that linchpin of Freirean dialogics, conscientização, a deepened historical and situational awareness that enables intervention or transformative praxis. Less obvious, perhaps, is the fact that Bakhtin's superaddressee reiterates another key Freirean theme, one that gained increasing importance in Freire's later writings but was evident throughout all of his work. This is the theme of hope.

Nor yet can dialogue exist without hope. Hope is rooted in men's incompletion, from which they move out in constant search.... Hopelessness is a form of silence, of denying the world and fleeing from it. The dehumanization resulting from an unjust order is not a cause for despair, but for hope, leading to the incessant pursuit of the humanity denied by injustice. Hope, however, does not consist in crossing one's arms and waiting. As long as I fight, I am moved by hope.... Dialogue cannot be carried on in a climate of hopelessness. If the dialoguers expect nothing to come of their efforts, their encounter will be empty and sterile, bureaucratic and tedious. (80)

Understood in the way I have outlined here, Bakhtin's superaddressee may embody the very hope to which Freire refers-a hope for discursive contexts that allow for a more just hearing, of imagined futures where our deepest sense of what a "good life" entails might yet be redeemed.

\section{Commitment Fraught With Possibility}

I began this essay by setting forth a problem that too often, I believe, accompanies a cultural studies approach to writing instruction-namely, the perception among students that cultural critique is a privileged, elitist mode of inquiry, one that is largely indifferent to, if not contemptuous of, those it presumably seeks to enlighten or liberate. I then argued that a dialogic, specifically Bakhtinian approach to response could help us address this problem, and offered a discussion of how two Bakhtinian concepts-anacrisis and the superaddressee — might be applied to our writing classrooms.

Underlying what I have attempted here is my belief that cultural critique needs dial ogue to restrain its tendencies for authoritarian pronouncements, for "last word" truisms and disabling certainties, for what Freire would call 
its sectarianism. But, likewise, dialogue needs critique to oppose its often blithe indifference to power relations, and how these relations shape the very conditions for speaking and, of course, writing. Composition teachers who see the value of both dialogue and critique will, however, be faced with a difficult negotiation. Willing neither to silence our own commitments nor to require that the same be espoused by our students, desiring from students neither an intimidated assent nor an unchallenged answer, teachers who embrace both dialogue and cultural studies find themselves inhabiting an always precarious territory of the between. In our class discussions, in our assignments, in our responses to student work, as well as in every other aspect of our pedagogies, we pitch camp on the borderlines, for there and only there are we able to meet our twin obligations to mutual inquiry, dialogue, and to the critique of how popular forms underwrite existing power relations in the most quotidian of ways.

If we fail to inhabit this borderline, I believe, our writing courses will likely engender the sorts of resentments that led one of my students, Sam, to suspect that in the eyes of critics, he is little more than a fool. Or, for another, Barbara, to cast herself (defiantly) as a "couch potato," the kind of person she believes to be more deserving of her loyalties than the cultural critic. Without a stake and a say in how their experience should be investigated, represented, and understood by the many others eager to speak for them, our students will make little sense of cultural studies. And while this state of affairs is sometimes understandable, it is not inevitable.

\section{Notes}

1. I would be remiss if I did not acknowledge Alan France's evaluation of Ways of Reading, particularly the 3rd edition which I used. France is congenially disposed to this work, but finds in its strong textual emphasis, "an acquiescence in the extant distribution of power" that rivals "expressivism's autonomous subject" (602). The authors' (post)structural textualism is set against France's preferred "materialist reading," and while the 3rd edition receives greater praise than the earlier two, it likewise comes up short in its wavering "commitment to a Marxist critique" (606). This rather severe judgment upon the left credentials of Ways of Reading, interestingly enough, recalls a criticism leveled at cultural studies in general-a criticism, according to Michael Bérubé, inclined to describe cultural studies as "Marxism Lite," hegemony as a "kinder and gentler" domination, and the practice of cul- tural studies as "a way for neopopulist intellectuals to get down with the people by writing about how much everybody loves Terminator 2 and Murphy Brown" (139-40). While not denying that cultural studies departs from received forms of Marxist thought, Bérubé defends cultural studies against these charges, pointing out where it differs significantly from traditional Marxisms in ways that are clearly useful, compelling, and historically appropriate. Though I feel no similar need to defend Ways of Reading against France's critique, I would suggest that France lends credence to the strong textualism he decries by apparently suggesting that teachers and students are unable to appropriate this text in ways that the editors did not intend, or could not imagine.

2. Knowing that my students were aware of my sympathies for both cultural studies and their resistance to it, and self-conscious 
of my obvious affiliation with that caste of "privileged revealers" who inhabit English departments, I specified myself as the audience for this assignment. I did so believing that having to write for this (very) familiar audience might complicate their writerly task in ways that could be rhetorically instructive-or failing that, occasionally interesting. What emerged, though, were papers whose collective need to answer Miller and Fiske encouraged my students to write for each other, perhaps as a community under siege, rather than for their originally stated audience. In fact, this served as the occasion to draw an ironic parallel to a charge I heard often in our class discussions, that critics like Miller and Fiske are only capable of writing for other critics like themselves.

3. The author would like to express gratitude to all members of his English 3810-001 class, Spring of 1995, especially to those whose work is cited here. Permission to use excerpts from student authors was obtained prior to the submission of this article. All names are fictional.

4. In one sense, what Alex offers here is a version of what Bernard Williams (after Aristotle) calls the Coriolanus paradox, a reference to those who "tend to defeat themselves by making themselves dependent on those to whom they aim to be superior" (39).

5. For a fuller discussion of Bakhtin's appropriation of Socrates, see Zappen.

6. See, for example, Eagleton's Literary Theory, especially 205-17. It might be suggested that I have confused a traditional Aristotelian rhetoric of persuasion with the redefinition offered by Eagleton that empha-

\section{Works Cited}

Bakhtin, M. M. "Author and Hero in Aesthetic Activity." Art and Answerability: Early Philosophical Essays by M. M. Bakhtin. Ed. Michael Holquist and Vadim Liapunov. Austin: U of Texas P, 1990. 4-256.

- - - Problems of Dostoevsky's Poetics. Ed. and trans. Caryl Emerson. Minneapolis: $U$ of Minnesota P, 1984. - Rabelais and His World. Trans. Hélène Iswolski. Bloomington: Indiana UP, 1965. . Speech Genres and Other Late E ssays.

Ed. Caryl Emerson and Michael Holquist. Trans. Vern W. McGee. Austin: U of TexasP, 1986. sizes the effects of discourse in social and cultural contexts. But these are hardly unrelated concerns. Any understanding of cultural studies will proceed on the assumption that the question of how minds are made cannot be separated from the problem of how minds are changed.

7. In identifying "attitude" as the "sixth term" of his Pentad, Kenneth Burke may help explain this point. Burke defines attitude as incipient action, and since, for Bakhtin, the tones of our words reveal, more than anything else, our attitudes, our "slants on the world," then every utterance we make is not simply a "literal" act; it is also the positing of a future act that has yet to come to fruition, but which nonetheless motivates what we utter in the immediate contexts in which we speak.

8. In fact, Bakhtin will often allude to this problem in other essays of the period, as well as in comments that he made before his death in 1975. In an interview with Sergey Bocharov, Bakhtin reveals that he "was fascinated by the problem of distant contexts-I started working on it several times back in the 1920s, but I didn't get very far, beyond starting." After which, Bakhtin adds ironically, "There was no distant context for such a work" (qtd. in Bocharov 1021).

9. The most obvious difference is that Habermas wants to identify a regulative model of the "ideal speech situation." Thus, Habermas thinks it possible to apprehend what is universal, rule-governed, and repeatable in instances of perfect communication, to ascertain what Thomas Kent has called "the language of parole" (284). Unlike Habermas, Bakhtin has no such desire.

Bartholomae, David, and Anthony Petrosky, eds. Ways of Reading: An Anthology for Writers. 3rd ed. Boston: St. Martin's, 1993.

Berlin, J ames A. "Composition Studies and Cultural Studies: Collapsing Boundaries." Into the Field: Sites of Composition Studies. Ed. Anne Ruggles Gere. New York, MLA, 1993. 99-116.

Bernstein, Michael André. "When the Carnival Turns Bitter: Preliminary Reflections Upon the Abject Hero." Bakhtin: Essays and Dialogues on His Work. Ed. Gary Saul Morson. Chicago: U of Chicago P, 1986. 99-121. 
Bernard-Donals, Michael. "Mikhail Bakhtin: Between Phenomenology and Marxism." College English 56 (1994): 170-88.

Bérubé, Michael. Public A ccess: Literary Theory and American Cultural Politics. London: Verso, 1994

Bialostosky, Don. “Dialogic Criticism.” Contemporary Literary Theory. Ed G. Douglas Atkins and Laura Morrow. Amherst: $U$ of Massachusetts P, 1989. 214-28.

Bocharov, Sergey. "Conversations with Bakhtin." Trans. Stephen Blackwell. Ed. Vadim Liapunov. PMLA 109 (1994): 1009-24.

Burke, Kenneth. A Grammar of M otives. Berkeley: U of California P, 1969.

Dixon, Kathleen. "Making and Taking Apart 'Culture' in the (Writing) Classroom." Left Margins: Cultural Studies and Composition Pedagogy. Eds. Karen Fitts and Alan W. France. New York: State U of New York P, 1995. 99-114.

Eagleton, Terry. Ideology: An Introduction. London: Verso, 1991.

- - - Literary Theory. Minneapolis: $U$ of Minnesota $\mathrm{P}, 1983$.

___- Walter Benjamin: Or Towards A Revolutionary Criticism. London: Verso, 1981.

Fiske, J ohn. "Madonna." Bartholomae and Petrosky 156-73.

Fogel, Aaron. "Coerced Speech and the Oedipus Dialogue Complex." Rethinking Bakhtin: Extensions and Challenges. Ed. Gary Saul Morson and Caryl Emerson. Evanston: Northwestern UP, 1989. 173-96.

France, Alan W. "Assigning Places: The Function of Introductory Composition as a Cultural Discourse." College English 55 (1993): 593-609.

Freire, Paulo. Pedagogy of the Oppressed.

Trans. Myra Bergman Ramos. New York: Continuum, 1970.

Gardiner, Michael. The Dialogics of Critique: M. M. Bakhtin and the Theory of Ideology. New York: Routledge, 1992.

George, Diana, and Diana Shoos. "Issues of Subjectivity and Resistance: Cultural Studies in the Composition Classroom." Cultural Studies in the English Classroom. Ed. J ames A. Berlin and Michael J. Vivion. Portsmouth: Boynton/Cook, 1992. 200-10.
Grover, J an Zita. "AIDS, Keywords, and Cultural Work." Cultural Studies. Ed. Lawrence Grossberg, Cary Nelson, and Paula Treichler. New York: Routledge, 1992. 227-39.

Grossberg, Lawrence. "Pedagogy in the Present: Politics, Postmodernity, and the Present." Popular Culture, Schooling, and Everyday Life. Ed. Henry Giroux and Roger Simon. New York: Bergin and Garvey, 1989. 91-115.

Habermas, Jürgen. Communication and the Evolution of Society. Trans. Thomas McCarthy. Boston: Beacon, 1979. . The Theory of Communicative Action. 2 vols. Trans. Thomas McCarthy. Boston: Beacon, 1984.

Harris, J oseph. "The Other Reader." J ournal of Advanced Composition 12 (1992): 27-37.

Holquist, Michael. Dialogism: Bakhtin and $\mathrm{H}$ is World. New York: Routledge, 1990.

- - - Introduction. Speech Genres and Other Late E ssays by M. M. Bakhtin. Austin: $U$ of Texas P, 1986. ix-xxiii.

Kent, Thomas. "Hermeneutics and Genre: Bakhtin and the Problem of Communicative Action." The Interpretive Turn. Ed. Davis Hiley, et al. Ithaca: Cornell UP, 1991. 282-303.

Lazere, Donald. "Teaching the Political Conflicts: A Rhetorical Schema." CCC 43 (1992): 194-213.

McComiskey, Bruce. "Social-Process Rhetorical Inquiry: Cultural Studies Methodologies for Critical Writing about Advertisements." J ournal of Advanced Composition 17 (1997): 381-400.

Miller, Mark Crispin. "Getting Dirty" and "Cosby Knows Best." Bartholomae and Petrosky 358-76.

Welch, Nancy. “One Student's Many Voices: Reading, Writing, and Responding with Bakhtin." J ournal of A dvanced Composition 13 (1993): 493-502.

Williams, Bernard. Ethics and the Limits of Philosophy. Cambridge: Harvard UP, 1985.

Zappen, J ames P. "Bakhtin's Socrates." Rhetoric Review 15 (1996): 66-83. 